\title{
The potential for using alcohol and tobacco taxes to fund prevention and control of noncommunicable diseases in Caribbean Community countries
}

\author{
Althea La Foucade, ${ }^{1}$ Charmaine Metivier, ${ }^{1}$ Samuel Gabriel, ${ }^{1}$ Ewan Scott, ${ }^{2}$ \\ Karl Theodore, ${ }^{1}$ and Christine Laptiste ${ }^{1}$
} countries. Rev Panam Salud Publica. 2018;42:e192. https://doi.org/10.26633/RPSP.2018.192

ABSTRACT Objectives. To determine the extent to which increased taxes on alcohol and tobacco products in Caribbean Community (CARICOM) countries might successfully reduce consumption of those products and raise revenues, which could then be channeled into noncommunicable disease (NCD) prevention and control initiatives.

Methods. The Tobacco Tax Simulation (TaXSiM) model, which was developed by the World Health Organization (WHO), was used to simulate the impact of tax changes on alcohol and tobacco products in three CARICOM member countries. Estimates of the NCD response cost in the 15 countries that are full members of CARICOM were also produced.

Results. For the 15 full-member CARICOM countries, the revenues from increased excise taxes on beer, rum, and cigarettes associated with a 5.0\% reduction in consumption were estimated at US\$ 86.32 million. This expected revenue intake from excise taxes exceeded the estimated US\$52.73 million required to respond to NCDs in those 15 CARICOM countries. The amount also exceeds US\$ 78.87 million, which will be required if there is a $50.0 \%$ increase in the per capita NCD response cost.

Conclusions. The findings showed that for CARICOM countries, there is a substantial potential for revenue generation from increases in taxes on alcohol and tobacco, as well as for decreases in consumption of the products. Although increased taxes on alcohol and cigarettes can sufficiently cover the cost of controlling NCDs among CARICOM countries, a comprehensive response also requires widespread participation from various sectors.

Keywords Alcoholic beverages; tobacco; taxes; noncommunicable diseases; West Indies; Caribbean Region.

Between 1990 and 2015, the pattern of diseases in the world shifted from communicable diseases to noncommunicable

\footnotetext{
The University of the West Indies, HEU, Centre for Health Economics, St. Augustine, Trinidad and Tobago. Send correspondence to Charmaine Metivier at Charmaine.Metivier@sta.uwi.edu

2 The University of the West Indies, Department of Economics, St. Augustine, Trinidad and Tobago.
}

diseases (NCDs), and so has the associated burden (1). This epidemiological transition, which began almost three decades ago, has fully taken hold. Globally, NCDs continue to be a major development challenge, annually killing 15 million persons between the ages of 30 and 70 years (2).
The Caribbean Community (CARI$\mathrm{COM})$ is a trade and economic bloc located in the Caribbean Basin and comprises 15 mostly English-speaking, full-member countries and 5 associatemember territories. (Not all Caribbean countries are CARICOM members.) CARICOM members have not been 
spared from NCDs, as they contend with a high and rising disease burden linked to the high prevalence of cerebrovascular diseases, diabetes, cancer, and chronic respiratory diseases, fueled in part by tobacco use and harmful alcohol consumption (3). In the Englishspeaking CARICOM members, the risk of premature deaths from these four diseases ranges from $16.0 \%$ to $28.0 \%$, while the proportion of total deaths stemming from NCDs is above $80.0 \%$ for many countries (2). Trinidad and Tobago and Jamaica, respectively, experience 10000 and 15000 NCD-related deaths each year. In Grenada, this number is 700 per year (2). Death rates of lung cancer across CARICOM members are lower than the average for the Americas, ranging from 2.4 to 17.5 per 100000 population. In contrast, cerebrovascular diseases are higher among CARICOM members, ranging between 47.0 and 104.8 per 100000 population, as compared to the average of 34.8 for the Americas.

In Trinidad and Tobago, the economic burden of NCDs from tobacco consumption and harmful alcohol use is substantial. It is estimated that NCDs cost the country roughly US\$ 1.3 billion annually, or approximately $5.0 \%$ of the gross domestic product (GDP) (4). Cancer, for which tobacco use is its most important risk factor (5), costs the Government US\$ 0.3 billion each year (4).

The economic and disease burdens across CARICOM member countries have made it necessary to chart a regional, actionable response-including taxation on alcohol and tobacco products and other policy measures-to reverse the negative public health and socioeconomic impacts of NCDs.

\section{Theoretical justification for a fiscal solution}

The use of taxes by the State to discourage practices deemed harmful to individuals and society is not new. In 1776, Adam Smith argued that "sugar, rum, and tobacco are commodities which are ... extremely proper subjects of taxation" (6). Cordes and colleagues (7) have said that "taxing tobacco [and alcohol]... may bring private and social costs and returns into closer alignment by causing market prices to reflect more fully the external costs of smoking [and drinking]."
It is well established that higher taxes are the single most effective way to decrease consumption and encourage tobacco users to quit (8). Increased alcohol taxation has also been effective in depressing abusive drinking (9). For the most part, the general conclusion has been that it is possible to simultaneously diminish the consumption of tobacco $(8$, 10-13) and alcohol (14-17) while also raising additional tax revenues. Furthermore, the resultant reduction in consumption has yielded significant improvements in health outcomes $(9,17,18)$.

\section{Study objective}

The objective of this study was to determine the extent to which increased taxes on alcohol (beer and rum) products and tobacco products can successfully reduce consumption, as well as raise revenues that can be channeled into initiatives to prevent and control NCDs in CARICOM member countries. (In this article, "tobacco" refers to cigarettes, and the two words are used interchangeably.)

\section{MATERIALS AND METHODS}

\section{Approach}

The study undertook an in-depth analysis of tax systems, structures, and applied methodologies for simulating outputs related to prices, tax revenues, and consumption impacts on alcohol and tobacco in three CARICOM member countries: Grenada, Jamaica, and Trinidad and Tobago. The multipronged approach included: a) secondary data collection methods, with desk reviews of taxation policies and forecasting models; b) formal requests for data from country agencies; c) in-country visits to the three case-study countries and meetings with key stakeholders; and d) simulations using the Tobacco Tax Simulation (TaXSiM) model (19).

The TaXSiM model was developed by the World Health Organization (WHO) to help policymakers analyze and assess a country's tax policy measures and structures for tobacco products. This research extended the model's use to alcohol products. While the model was designed as a tobacco tax simulation tool, the basic workings of elasticity and tax rate changes and their effects on sales, price, and revenues are identical for other products. The major difference is that of the unit of measure for the products in question. Whereas cigarettes can be analyzed in terms of sticks or packs of a specified size (in this case, 20-stick packs), alcohol can be analyzed in terms of bottles or cases (of a specified size). In this analysis, 6.6-liter cases of beer and 9-liter cases of rum were analyzed.

Ultimately, the effects of tax changes on price and consumption will be influenced mainly by the elasticities and not necessarily by the unit of measure. The model separates products into brand/market segments based on price (premium, mid-price, and economy). Therefore, the assumption is that each brand/segment has a corresponding price elasticity of demand, which reflects the income strata of its consumers within the same sector. For cigarettes, price elasticity values ranging from -0.2 to -0.9 were used in the study. For alcohol, pooled estimates of price elasticity of demand of -0.50 for beer $(95.0 \%$ confidence interval (CI): -0.78 to -0.21 ) and -0.79 for other alcoholic beverages ( $95.0 \%$ CI: -1.09 to -0.49 ) in lowand middle-income countries were used (20).

\section{Simulations}

Data (tax rates, tax bases, price elasticities of demand by brand segment, sales volumes, final consumer price by brand, etc.) on the current tax system were entered in the model and baseline estimates were generated for several variables, including sales volumes (used as a proxy for consumption), total tax revenues, and total excise tax revenues. The excise tax rate was adjusted to effect a 5.0\%, 10.0\%, and $15.0 \%$ decrease in consumption of both products, and the resultant changes in key variables were examined. The base year for this study was 2014 .

All local country currencies were converted into US dollars using the following exchange rates: Jamaica: US\$ $1.00=\mathrm{JM} \$$ 111.30 (2014), US\$ $1.00=\mathrm{JM} \$ 117.31$ (2015), according to the Bank of Jamaica (21); Trinidad and Tobago: US\$ $1.00=$ TT\$ 6.3613 (2014), US\$ $1.00=$ TT\$ 6.3298 (2015), according to the Central Bank of Trinidad and Tobago (22); and Grenada: US\$ $1.00=$ Eastern Caribbean dollars (EC\$) 2.70 (exchange rate fixed), according to the Eastern Caribbean Central Bank (23).

\section{Smuggling trigger tax rate}

The TaXSiM model does not identify the tax rate at which smuggling occurs, so the basic principles of demand and 
supply were used to determine a smuggling trigger tax rate for alcohol and cigarettes. On the demand side, there is smuggling hoped for by consumers, while smuggling planned for by suppliers represents the supply side. The assumption is that smugglers of alcohol and tobacco will want to supply the market with the quantity of goods equivalent to that which is hoped for by consumers of the smuggled products.

Consumers' behavior provides a basis for the assumption that the amount of smuggling hoped for will be at a level at which pretax consumption will not fall significantly. When there is a significant fall in consumers' surplus, the assumption is that some consumers will hope for and search out smuggled products, given their low elasticities, while other consumers will be satisfied with keeping their consumption constant. Therefore, consumer surplus provides a good indicator of the level of enjoyment (consumption) of the products at a given price. (In the mid-nineteenth century, French engineer Jules Dupuit first propounded the concept of economic surplus, but it was the economist Alfred Marshall who gave the concept its fame in his Principles of Economics text (24)).

The linear demand curve shows the proportional relationship between changes in consumer surplus and changes in consumption levels. This analysis therefore uses changes in the level of consumption as a proxy for changes in consumer surplus $(25,26)$. This study assumes that consumption changes below $10.0 \%$ will not affect consumer surplus significantly. Without available empirical analysis of smuggling in the Caribbean, it is reasonable to assume that smuggling exists to maintain consumption levels and therefore there will be a particular level of consumption that will act as a trigger. Hence, the tax rate that results in consumption decreasing by $10.0 \%$ or more is the tax rate that triggers smuggling on the demand side. For example, an elasticity of -0.6 and a price increase of $16.7 \%$ will result in a $10.0 \%$ fall in consumption. Based on the prior analysis, this will be the smuggling trigger rate. With an elasticity of -0.4 , only with a price increase of $25.0 \%$ will the smuggling trigger rate be expected to emerge. Hence, the more inelastic the demand for the products, the higher the tax rate required to trigger smuggling.

\section{Alcohol and tobacco tax systems in the case-study countries}

There were six main categories of tobacco- and alcohol-related taxes in effect in 2014 in the three selected
CARICOM countries: 1) import duty/ common external tariff; 2) excise tax/ special consumption tax; 3) Divide as one or the other way: value-added tax OR value-add-ed tax 4) customs service charge; 5) additional stamp duty; and 6) environmental levy (Table 1). Across the chosen countries, import duties on the products range from $30.0 \%$ to $50.07 \%$, while all countries apply a common VAT of $15 \%$. Furthermore, excise taxes are applied on all of the products, albeit at different rates.

\section{RESULTS}

\section{Revenue and consumption estimates}

The TaXSiM process shows that the reduction in consumption through the increase in the excise tax rate can achieve positive revenue outcomes in all three consumption reduction scenarios, across all three case-study countries (Table 2).

In the case of Jamaica, a $5.0 \%$ fall in consumption of beer is associated with an increase in related excise revenues of US\$ 3.26 million. For rum and cigarettes, the Government can expect to raise an additional US\$ 1.86 million and US\$ 5.91 million, respectively. In the $10.0 \%$ and $15.0 \%$ consumption reduction scenarios, excise revenues are forecast to increase

TABLE 1. Alcohol and tobacco tax systems in the three case-study countries, 2014, in study of potential for using alcohol and tobacco taxes to fund prevention and control of noncommunicable diseases in the Caribbean Community member countries

\begin{tabular}{|c|c|c|c|c|c|c|}
\hline \multirow{2}{*}{ Tax system } & \multicolumn{2}{|c|}{ Jamaica } & \multicolumn{2}{|c|}{ Trinidad and Tobago } & \multicolumn{2}{|c|}{ Grenada } \\
\hline & Cigarettes & Alcohol & Cigarettes & Alcohol & Cigarettes & Alcohol \\
\hline Import duty/CETa & $30.0 \%$ & $30.0 \%$ & $50.1 \%$ of CIF value & $\begin{array}{c}\text { US\$ } 12.09 \text { (ABV }{ }^{b} \text { rum) } \\
\text { US\$ } 1.38 \text { (ABV, beer) } \\
\text { US\$1.73 (ABV, stout) }\end{array}$ & $35.0 \%$ & $35.0 \%$ \\
\hline $\begin{array}{l}\text { Excise tax/Special } \\
\text { consumption tax }\end{array}$ & $\begin{array}{l}\text { US\$ } 0.09 \text { per } \\
\text { stick }\end{array}$ & $\begin{array}{l}\text { US\$ } 10.06 \text { per } \\
\text { liter (rum \& beer) }\end{array}$ & $\begin{array}{c}\text { US\$ } 0.60 \\
\text { per pack of } 20 \text { sticks }\end{array}$ & $\begin{array}{c}\text { US\$ } 10.38 \text { per liter (ABV, rum); US\$ } \\
0.67 \text { per liter (ABV, beer \& stout) }\end{array}$ & $\begin{array}{l}95.0 \% \text { of } \mathrm{CIF}^{\mathrm{c}} \text { value } \\
\text { compounded }\end{array}$ & $\begin{array}{c}\text { US\$ } 1.48 \\
\text { per liter (ABV) }\end{array}$ \\
\hline $\begin{array}{l}\text { VAT } / \text { General } \\
\text { consumption tax }\end{array}$ & $15.0 \%$ & $15.0 \%$ & $15.0 \%$ & $15.0 \%$ & $15.0 \%$ & $15.0 \%$ \\
\hline Customs service charge & $N A^{e}$ & NA & NA & NA & $6.0 \%$ & $6.0 \%$ \\
\hline Environmental levy & NA & NA & NA & NA & NA & $\begin{array}{c}\text { US\$ } 0.09 \text { per liter } \\
\text { (beer, stout, some } \\
\text { rum) }\end{array}$ \\
\hline Additional stamp duty & $\begin{array}{l}\text { Ranges between } \\
6.0 \% \text { and } 56.0 \%\end{array}$ & $\begin{array}{c}34.0 \% \\
\text { (wine, beer, rum) }\end{array}$ & NA & NA & NA & NA \\
\hline
\end{tabular}

Source: Constructed by authors from data for 2014 gathered from statistical offices and customs and excise divisions in the case-study countries.

a CET = common external tariff.

${ }^{\mathrm{b}} \mathrm{ABV}=$ alcohol by volume.

${ }^{\circ} \mathrm{CIF}=$ cost, insurance, and freight.

${ }^{\mathrm{d}} \mathrm{VAT}=$ value-added tax .

${ }^{\text {e }} \mathrm{NA}=$ not applicable. 
TABLE 2. Results of the TaXSiM simulations in the three case-study countries, with falls in consumption of $5 \%$, $10 \%$, and $15 \%$, and the associated revenue increases, in percent and in US dollars (millions), 2015

\begin{tabular}{|c|c|c|c|c|c|c|c|c|c|c|c|c|}
\hline \multirow[t]{2}{*}{ Product/Government revenue } & \multicolumn{4}{|c|}{ Jamaica } & \multicolumn{4}{|c|}{ Trinidad and Tobago } & \multicolumn{4}{|c|}{ Grenada } \\
\hline & $\begin{array}{c}\text { Baseline } \\
2014\end{array}$ & $-5.0 \%$ & $-10.0 \%$ & $-15.0 \%$ & $\begin{array}{c}\text { Baseline } \\
2014 \\
\end{array}$ & $-5.0 \%$ & $-10.0 \%$ & $-15.0 \%$ & $\begin{array}{c}\text { Baseline } \\
2014 \\
\end{array}$ & $-5.0 \%$ & $-10.0 \%$ & $-15.0 \%$ \\
\hline \multicolumn{13}{|l|}{$\overline{\text { Beer }}$} \\
\hline Excise revenues (\% increase) & & $46.2 \%$ & $85.6 \%$ & $118.3 \%$ & & $27.7 \%$ & $51.0 \%$ & $71.1 \%$ & & $266.6 \%$ & $515.1 \%$ & $713.1 \%$ \\
\hline Total revenues (increase) & US\$ 21.72 & US\$ 3.34 & US\$ 6.13 & US\$ 8.36 & US\$ 3.17 & US\$ 0.48 & US\$ 0.88 & US\$ 1.22 & US\$ 2.46 & US\$ 0.83 & US\$ 1.58 & US\$ 2.17 \\
\hline Excise revenues (increase) & US\$ 18.05 & US\$ 1.86 & US\$ 3.37 & US\$ 4.65 & US\$ 24.07 & US\$ 1.54 & US\$ 2.78 & US\$ 3.78 & US\$ 0.54 & US\$ 0.26 & US\$ 0.50 & US\$ 0.71 \\
\hline Excise revenues (\% increase) & & $10.9 \%$ & $19.7 \%$ & $27.1 \%$ & & $6.4 \%$ & $11.5 \%$ & $15.4 \%$ & & $47.6 \%$ & $93.8 \%$ & $132.5 \%$ \\
\hline Total revenues increase) & US\$ 45.76 & US\$ 2.08 & US\$ 3.64 & US\$ 4.81 & US\$ 30.97 & US\$ 1.60 & US\$ 2.86 & US\$ 3.78 & US\$ 1.15 & US\$ 0.25 & US\$ 0.53 & US $\$ 0.74$ \\
\hline Total revenues ( $\%$ increase) & & $4.8 \%$ & $8.4 \%$ & $11.1 \%$ & & $5.2 \%$ & $9.2 \%$ & $12.1 \%$ & & $21.4 \%$ & $45.7 \%$ & $64.1 \%$ \\
\hline \multicolumn{13}{|l|}{ Cigarettes } \\
\hline Excise revenues (increase) & US\$ 40.87 & US\$ 5.91 & US\$ 10.97 & US\$ 15.11 & US\$ 24.42 & US\$ 6.33 & US\$ 11.67 & US\$ 16.25 & US\$ 1.32 & US\$ 0.15 & US\$ 0.28 & US\$ 0.39 \\
\hline
\end{tabular}

Source: Authors' estimates, based on study results.

TABLE 3. Comparison of World Health Organization's per capita cost for NCD control of noncommunicable diseases, estimated per capita excise revenues, and estimated total excise revenues, with 2015 population estimates for the three Caribbean Community member countries

\begin{tabular}{|c|c|c|c|c|}
\hline Characteristic & Jamaica & Trinidad and Tobago & Grenada & Total/Overall \\
\hline Population (2015) & 2723000 & 1349667 & 110566 & 4183233 \\
\hline Estimated total excise revenues & US\$11000 027 & US\$ 8338000 & US\$ 1209000 & US\$ 20547027 \\
\hline Estim & US: &  & US\$ & US\$ $4.91^{\mathrm{a}}$ \\
\hline WHO $0^{b}$ per capita cost for $\mathrm{NCD}^{\mathrm{c}}$ control & US\$ 3.00 & US\$ 3.00 & US\$ 3.00 & $N A^{d}$ \\
\hline
\end{tabular}

\section{Source: Authors' estimates; World Health Organization; Caribbean Community Secretariat.}

a Per capita potential excise revenues of US $\$ 4.91$ were estimated by dividing the total projected excise revenues

(US\$20.55 million) for the three case-study countries by the total population of the three countries.

${ }^{b}$ WHO $=$ World Health Organization.

${ }^{\circ} \mathrm{NCD}=$ noncommunicable disease.

${ }^{\mathrm{N}} \mathrm{NA}=$ not applicable.

by between US\$ 3.37 million $(10.0 \%$, rum) and US\$ 15.11 million (15.0\%, cigarettes).

The results for Trinidad and Tobago indicate that tax-induced reductions in cigarette consumption of $5.0 \%, 10.0 \%$, and $15.0 \%$ are estimated to generate US\$ 6.33 million, US\$ 11.67 million, and US\$ 16.25 million, respectively, in additional cigarette-related excise revenues. For rum, the model predicts that excise revenues will increase by US\$ 1.54 million, US\$ 2.78 million, and US\$ 3.78 million in the $5.0 \%, 10.0 \%$, and $15.0 \%$ consumption reduction scenarios, respectively. Excise tax revenues from beer can be expected to grow by between US $\$ 0.47$ million and US\$ 1.21 million.

For Grenada, $5.0 \%, 10.0 \%$, and $15.0 \%$ decreases in rum consumption, stem- ming from excise tax increases, are likely to yield rum-related excise tax revenue growth of US\$ 0.26 million, US\$ 0.50 million, and US\$ 0.71 million, respectively. Tax-induced beer intake reductions show associated excise revenue increases ranging from US\$ 0.81 million to US\$ 2.16 million. Revenue growth for cigarettes ranges from US\$ 0.15 million to US\$ 0.39 million.

Table 2 summarizes the results of the simulations in the three case-study countries, while Table 3 shows the per capita revenue estimates from increased taxes on the products.

\section{Smuggling trigger tax rate}

Based on the hypothesis presented in the earlier discussion in this article of the smuggling trigger tax rate, elevated levels of smuggling will be triggered at the average excise tax rate that induces a $10.0 \%$ or greater fall in consumption.

Elevated levels of smuggling in Jamaica are predicted to take effect when the average excise tax rate is US\$ 7.20 for beer (per 6.6-liter case) and is US\$ 56.77 for rum (per 9-liter case). The smuggling trigger for cigarettes is predicted to be at US\$ 2.56 (per pack of 20).

For Trinidad and Tobago, smuggling of the products is predicted to elevate when the excise tax is US\$ 7.44 for beer (per 6.6-liter case) and is US\$ 66.78 for rum (per 9-liter case). Smuggling of cigarettes is predicted to increase at a trigger excise tax rate of US\$ 1.00 (per pack of 20).

In Grenada, with a fall in consumption of $10.0 \%$, elevated levels of smuggling were predicted at a US\$ 3.52 average excise tax rate for beer (per case of 6.6 liters), US\$ 20.24 average excise tax rate for rum (per case of 9 liters), and at $133.5 \%$ of cost, insurance, and freight value for cigarettes.

\section{DISCUSSION}

\section{Revenue-raising potential from alcohol and tobacco taxes}

The simulation results provide the basis for a discussion on the potential revenues to be derived from an in- 
crease in excise taxes on alcohol and tobacco. The analysis of excise tax revenues alone shows that a tax-induced $5.0 \%$ fall in consumption increases revenues for the three case-study countries by a total of US\$ 20.55 million. This estimate represents the potential revenues that can result from changes in excise taxes on cigarettes, beer, and rum. In some cases (e.g. Trinidad and Tobago) only locally manufactured rum was used in the analysis. These sales totals therefore represent a sample of total sales. This may result in assessments for rum being underestimated.

The potential revenues from increased taxes on alcohol and tobacco in the 15 CARICOM full-member countries were estimated using a simple mathematical formula. Total projected excise revenues (US\$20.55 million) for the 3 case-study countries were divided by the total population of the three countries, which produced a per capita potential excise revenue of US\$ 4.91 (Table 3). These individual country per capita revenues were found to be higher than the WHO per capita cost of US\$ 3.00 for funding the NCD response (27). The total expected excise revenues for the 15 full-member countries in CARICOM were calculated by multiplying the total population of 17575 151 in those nations (midyear population estimates for 2015 (28)) by the per capita excise revenues of US\$ 4.91, which resulted in total expected excise revenues of US\$ 86.32 million. Given the similar economic, social, and cultural environments of many of the CARICOM countries, it is reasonable to assume the outcomes of the three casestudy countries will be mirrored in most of the CARICOM countries.

Higher combined revenue levels are expected with the $10.0 \%$ and $15.0 \%$ consumption reduction scenarios and when the full suite of taxes (excise taxes, import duties, VAT, etc.) are levied on the products. Therefore, the potential revenues predicted in this study may very well be conservative estimates.

This analysis indicates that CARICOM countries have the capacity (via taxes) to implement effective measures to reduce the consumption of alcoholic beverages and cigarettes without immediate concerns for loss in overall tax revenues from these products.

\section{Using tax revenues to fund NCD prevention and control measures}

This study suggests that the potential revenues that can be generated from increases in alcohol and tobacco taxes are substantial enough to finance the NCD response, once appropriately applied. With the per capita cost of the NCD response estimated at US\$ 3.00 in middle-income countries (27), the total cost would be US\$ 12.55 million for Grenada, Jamaica, and Trinidad and Tobago, which have a combined population of 4.18 million. If the WHO-suggested per capita cost was to increase by $50.0 \%$ to US\$ 4.50 , the NCD response effort would amount to US\$ 18.81 million for these three nations.

For the three countries, potential excise revenues of US\$ 20.55 million are associated with the predicted $5.0 \%$ fall in consumption, with additional revenues expected with further tax increases. Thus, it is fair to suggest that the expected revenues would be sufficient to fund an effective NCD response.

For the 15 CARICOM full-member countries, the estimated cost for the NCD response is US\$ 52.73 million (total 2015 population of the 15 CARICOM full-member countries of $17575151 \mathrm{X}$ US\$ 3.00 per capita $=$ US\$ 52725 453). The expected revenue from excise taxes is US\$ 86.32 million, based on the $5.0 \%$ consumption reduction scenario. With an increase in the per capita treatment cost to US\$ 4.50, the total NCD response cost to CARICOM full-member countries would be US\$ 78.87 million, well within the expected revenue intake from excise taxes on beer, rum, and cigarettes. If there were a doubling of the per capita response cost (to US\$ 6.00), this amounts to US\$ 105 million for the 15 full-member countries of CARICOM. This sum is barely in excess of the revenues that can be raised from a targeted $5.0 \%$ fall in consumption.

\section{Limitations of the study}

Some of the limitations of this study are linked to the use of the TaXSiM model.

First, although smuggling was postulated to be triggered by a taxation level that depresses consumption beyond a certain point, the model did not have enough structure to estimate the expected smuggling. This remains to be done.
Second, the study was limited to the use of sales data for some countries, but these data may not represent the total volume of the products sold/consumed. In such instances, estimates of revenues will be underestimated.

Third, although the price elasticities used in the analysis are quite reasonable, the consumption effects may be underestimated because the TaXSiM model does not allow for income elasticities.

Fourth, the model is not able to forecast how the manufacturers of alcohol and tobacco will respond to various taxation policies and, as such, estimates are based on current market conditions. Finally, the model is unable to explicitly compensate for the illicit trade in the products that may ensue as the prices of the products rise to certain levels.

\section{Conclusions}

The analysis showed that increases in taxation would reduce tobacco and alcohol consumption. In fact, tax rates were identified at which consumption declines of $5.0 \%, 10.0 \%$, and $15.0 \%$ would take place.

The study also showed that for the 15 CARICOM full-member countries, there is significant potential for revenue generation (in excess of US\$ 86.32 million) from increases in taxes on alcohol and tobacco, alongside decreases in consumption of the products. This analysis suggests that increased taxes on alcohol and cigarettes can sufficiently cover the cost of the NCD response effort in those CARICOM full-member countries. The study provides sufficient financially grounded evidence for increasing taxes and directing the revenue flows toward NCD interventions, with the aim of better health outcomes for the population in the CARICOM member countries. However, it is important to note that any comprehensive NCD response cannot rest solely on taxation measures. An adequate response will require critical contributions from the health sector and widespread participation from other sectors as well.

\section{Recommendations}

Two main recommendations come from this study. First, CARICOM countries should activate the agreement embodied in the Declaration of 
Port-of-Spain: Uniting to Stop the Epidemic of Chronic NCDs (29) and impose taxes on alcohol and tobacco as a means of raising revenues for responding to the health problems created by the consumption of these products. The Declaration resulted from a 2007 special regional summit on NCDs, where the CARICOM Heads of Government committed to in- troducing strategies to prevent and control NCDs by addressing their causal risk factors. Second, while acknowledging that taxation per se is not a cause of smuggling, this study recognizes that taxation beyond a certain level will make smuggling attractive. It is therefore key that CARICOM countries monitor the degree of smuggling taking place and be

\section{REFERENCES}

1. Institute for Health Metrics and Evaluation. Rethinking development and health: findings from the Global Burden of Disease Study. Available from: http://www. healthdata.org/policy-report/rethinkingdevelopment-and-health-findingsglobal-burden-disease-study Accessed 10 October 2018.

2. World Health Organization. Non communicable diseases progress monitor 2017. Available from: http://www.who.int/ nmh/publications/ncd-progress-monitor-2017/en/ Accessed 11 October 2018.

3. Pan American Health Organization. Indepth qualitative analysis of noncommunicable diseases. Multisectoral action plans in the Caribbean. Available from: http: / / iris.paho.org/xmlui/handle/123456789/49093 Accessed 11 July 2018.

4. Ministry of Health, Government of Trinidad and Tobago. National Strategic Plan for the Prevention and Control of Non Communicable Diseases: Trinidad and Tobago 2017 - 2021. Available from: www. health.gov.tt/downloads/DownloadItem. aspx?id=385 Accessed 11 October 2018.

5. World Health Organization. Cancer. Available from: http://www.who.int/cancer/ en/ Accessed 12 May 2018.

6. Smith A. An inquiry into the nature and causes of the wealth of nations. Chicago: University Of Chicago Press; 1977.

7. Cordes JJ, Nicholson EM, Sammartino FJ. Raising revenue by taxing activities with social costs. Natl Tax J. 1990;43(3):343-56.

8. World Health Organization. Raise taxes on tobacco when tobacco prices go up, consumption goes down. Available from: www.who.int/tobacco/mpower/publications/en_tfi_mpower_brochure_r. pdf\%0A\%0A Accessed 16 July 2018.

9. Zatoński WA, Sulkowska U, Zatoński MZ, Herbeć AA, Muszyńska MM. Alcohol taxation and premature mortality in Europe. Lancet. 2015;385(9974):1181.

10. Yeh CY, Schafferer C, Lee JM, Ho LM, Hsieh CJ. The effects of a rise in cigarette price on cigarette consumption, tobacco taxation revenues, and of smoking-related deaths in $28 \mathrm{EU}$ countries - applying threshold regression modelling. BMC Public Health. 2017;17(676):1-9.

11. Salti N, Chaaban J, Nakkash R, Alaouie H. The effect of taxation on tobacco consump- tion and public revenues in Lebanon. Tob Control. 2015;24(1):77-81.

12. Rodríguez-Iglesias $G$, Schoj V, Chaloupka F, Champagne B, González-Rozada M. Analysis of cigarette demand in Argentina: the impact of price changes on consumption and government revenues. Salud Publica Mex. 2017;59(1):95-101.

13. Walbeek C Van. The economics of tobacco control in Jamaica: Will the pursuit of public health place a fiscal burden on the government? Available from: http://www.tobaccoecon.uct.ac. $\mathrm{za} /$ sites/default/files/image_tool/images / 405/Publications/reports / TheEconomics-of-Tobacco-Control-in-Jamaica.-Will-the-Pursuit-of-PublicHealth-place-a-Fiscal-Burden-on-theGovernment.pdf Accessed 15 September 2014. gan DH. Employment impacts of alcohol taxes. Prev Med (Baltim). 2017;105(2017): S50-5.

15. Ye R. The effects of alcohol taxation and pricing policies on unrecorded alcohol consumption in Russia. J Alcohol Drug Depend. 2017;5(6):3.

16. Vandenberg B, Sharma A. Are alcohol taxation and pricing policies regressive? Product-level effects of a specific tax and a minimum unit price for alcohol. Alcohol Alcohol. 2016 Jul 1;51(4):493-502.

17. Stacey N, Summan A, Tugendhaft A, Laxminarayan R, Hofman K. Simulating the impact of excise taxation for disease prevention in low-income and middle-income countries: an application to South Africa. BMJ Glob Heal. 2018;3(1):1-6.

18. Meier PS, Holmes J, Angus C, Ally AK, Meng Y, Brennan A. Estimated effects of different alcohol taxation and price policies on health inequalities: a mathematical modelling study. PLoS Med. 2016; 13(2):1-27.

19. World Health Organization. The World Health Organization's Tobacco Tax Simulation Model (WHO TaXSiM). Available from: www.who.int/tobacco/economics/ taxsim_background.pdf Accessed 10 July 2015.

20. Sornpaisarn B, Shield K, Cohen J, Schwartz R, Rehm J. Elasticity of alcohol consumption, alcohol-related harms, and drinking initiation in low- and middle-income countries: a
14. Wada R, Chaloupka FJ, Powell LM, Jerni- mindful of tax rates that might trigger the phenomenon.

\section{Conflicts of interest. None declared.}

Disclaimer. Authors hold sole responsibility for the views expressed in the manuscript, which may not necessarily reflect the opinion or policy of the RPSP/ PAJPH or PAHO. systematic review and meta-analysis. Int J Alcohol Drug Res. 2013;2(1):45-58.

21. Bank of Jamaica. Annual average exchange rate. Available from: http://boj. org.jm/foreign_exchange/fx_rates_annual.php Accessed 18 July 2018.

22. Central Bank of Trinidad and Tobago. Exchange rates annual. Available from: https: / / www.central-bank.org.tt/statistics / data-centre/exchange-rates-annual Accessed 11 October 2018.

23. Eastern Caribbean Central Bank. Eastern Caribbean Central Bank. Available from: https://www.eccb-centralbank.org/ Accessed 18 December 2015.

24. Marshall A. Principles of economics. Available from: http://files.libertyfund. org / files / 1676/Marshall_0197_EBk_ v6.0.pdf Accessed 20 July 2018.

25. Henderson A. Consumer's surplus and the compensating variation. Rev Econ Stud. 1941;8(2):117-21.

26. Boulding KE. The concept of economic surplus. Am Econ Rev. 1945;35(5):851-69.

27. World Health Organization. Package of essential noncommunicable (PEN) disease interventions for primary health care in low-resource settings. Available from: https: / / www.who.int/nmh / publications/essential_ncd_interventions_lr_settings.pdf\%0A\%0A Accessed 14 March 2017.

28. Caribbean Community. Regional statistics. Available from: http://www.caricomstats.org/Pop_VS_LF.html Accessed 19 December 2015.

29. Caribbean Community. Declaration of Port-of-Spain: Uniting to Stop the Epidemic of Chronic NCDs. Available from: https:/ / c a r i com . org / m edia-center/ communications/statements-fromcaricom-meeting s / d eclaration -of-port-of-spain-uniting-to-stop-the-epidemic-of-chronic-ncds Accessed 25 October 2018.

Manuscript received on 22 December 2017. Revised version accepted for publication on 21 August 2018. 
RESUMEN Objetivo. Determinar hasta qué punto el aumento de los impuestos al alcohol y el tabaco en los países de la Comunidad del Caribe (CARICOM) podría reducir el consumo de esos productos y aumentar los ingresos públicos, recursos que posterior-

Uso potencial de los impuestos al alcohol y al tabaco para financiar la prevención y el control de las enfermedades no transmisibles en los países de la Comunidad del Caribe

Palabras clave mente podrían derivarse hacia iniciativas de prevención y control de enfermedades no transmisibles (ENT).

Métodos. Se empleó el modelo de Simulación de Impuestos al Tabaco (TaXSiM), desarrollado por la Organización Mundial de la Salud, para simular el impacto de los cambios impositivos sobre el alcohol y el tabaco en tres países miembros de la CARICOM, así como para estimar el costo de respuesta a las ENT en los 15 países que son miembros plenos de la CARICOM.

Resultados. Para los 15 países miembros plenos de la CARICOM, los ingresos públicos derivados del aumento de los impuestos al consumo de cerveza, ron y cigarrillos asociados con una reducción del consumo del 5.0\% se estimaron en USD 86,32 millones. Este ingreso esperado por impuestos al consumo excedió los USD 52,58 millones requeridos para responder a las ENT en esos 15 países de la CARICOM. Ese monto también supera los USD 78,87 millones que se requerirán si hay un aumento del $50.0 \%$ en el costo de respuesta per cápita a las ENT.

Conclusiones. Los hallazgos demostraron que, para los países de la CARICOM, existe un potencial importante para generar ingresos a partir del aumento de los impuestos al alcohol y el tabaco, así como para la disminución del consumo de estos productos. Aunque el aumento de los impuestos al alcohol y los cigarrillos puede cubrir suficientemente el costo de controlar las ENT en los países de la CARICOM, una respuesta integral requiere también la participación amplia de varios sectores.

Bebidas alcohólicas; tabaco; impuestos; enfermedades no transmisibles; Indias Occidentales; Región del Caribe.

RESUMO

\section{Uso potencial de impostos sobre o álcool e o tabaco para financiar a prevenção e o controle de doenças não transmissíveis nos países da Comunidade do Caribe}

Palavras-chave
Objetivo. Determinar em que medida o aumento dos impostos sobre o álcool e tabaco nos países da Comunidade do Caribe (CARICOM) poderia reduzir o consumo desses produtos e aumentar as receitas do governo, recursos que poderiam posteriormente ser desviados para iniciativas de prevenção e controle de doenças não transmissíveis (DNT).

Métodos. O modelo de Simulação Tributária do Tabaco (TaXSiM), desenvolvido pela Organização Mundial de Saúde, foi usado para simular o impacto das alterações fiscais sobre o álcool e tabaco em três países membros da CARICOM, bem para estimar o custo de resposta às DNT nos 15 países membros da CARICOM.

Resultados. Para os 15 países membros plenos da CARICOM, as receitas públicas do aumento de impostos sobre o consumo de cerveja, rum e cigarros, associadas a uma redução de 5,0\% no consumo, foram estimadas em USD 86,32 milhões. Essa receita esperada de impostos sobre o consumo excedeu os USD 52,58 milhões necessários para responder às DNT nesses 15 países da CARICOM. Esse valor também excede os USD 78,87 milhões que serão necessários se houver um aumento de 50,0\% no custo de resposta per capita às DNT.

Conclusões. Os resultados mostraram que para os países da CARICOM existe um potencial significativo para gerar receita a partir de aumentos nos impostos sobre álcool e tabaco, bem como para a diminuição no consumo desses produtos. Embora o aumento dos impostos sobre o álcool e cigarros possa cobrir suficientemente o custo de controle das DNT nos países da CARICOM, uma resposta abrangente requer também a participação ampla de diversos setores.

Bebidas alcoólicas; tabaco; impostos; doenças não transmissíveis; Índias Ocidentais; Região do Caribe. 